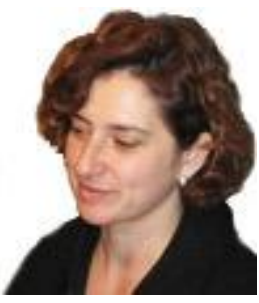

\title{
The use of technology in translation work placements
}

Olga Torres-Hostench

Universitat Autònoma de Barcelona olga.torres.hostench@uab.cat

\section{ABSTRACT}

Work placements are considered the natural step to take prior to obtaining full-time employment. Students would therefore benefit from instruments to guide them in their work placements and to invite them to reflect on their experience. This article is not a research work but a "food for thought" exercise for students, tutors and work placement coordinators in order to make technology visible and show that technological competences are inseparable from the other professional competences identified by the expert group for the European Master's in Translation.

Keywords: Translation; technology; translation technologies; translation work placements; European Master's in Translation; translation competences

\section{RESUM (L'ús de tecnologies en les pràctiques de traducció en empresa)}

Les pràctiques es consideren el pas previ a la inserció laboral. Per aquest motiu val la pena elaborar instruments que guiïn els estudiants en el seu procés de reflexió i aprofitament de les pràctiques. Aquest article no és un treball de recerca, sinó un exercici de reflexió per a estudiants, tutors i coordinadors de pràctiques que, d'una banda, intenta donar visibilitat a les tecnologies que es fan servir durant les pràctiques $\mathrm{i}$, d'altra banda, relaciona l'ús de la tecnologia amb les competències professionals proposades pel grup d'experts de l'European Master's in Translation.

Paraules clau: Traducció; tecnologia; tecnologies de la traducció; treball en pràctiques; Màster Europeu en Traducció; competències traductològiques

\section{RESUMEN (El uso de tecnologías en las prácticas de traducción en empresa)}

Las prácticas se consideran el paso previo a la inserción laboral. Por este motivo vale la pena elaborar instrumentos que guíen a los estudiantes en su proceso de reflexión y aprovechamiento de las prácticas. Este artículo no es un trabajo de investigación, sino un ejercicio de reflexión para estudiantes, tutores y coordinadores de prácticas que, por un lado, intenta dar visibilidad a las tecnologías que se utilizan durante las prácticas y, por otro lado, relaciona el uso de la tecnología con las competencias profesionales propuestas por el grupo de expertos del European Master's in Translation.

Palabras clave: Traducción; tecnología; tecnologías de la traducción; trabajo en prácticas; Máster Europeo en Traducción; competencias traductológicas

\section{Introduction}

During work placements, are students aware of the professional competences that they are practicing? Are they aware of the technology they are using during work placements? Is there a way to make technologies more visible? To what extent is technology important in translation work placements? Sometimes technological competences are seen as secondary 
competences. For some types of translations, however, such as multimedia and audiovisual localisation, technology skills are essential.

During their placements students practise what they have learned in the classroom and use software tools in a real-life context; companies, meanwhile, observe how the students interact with their computers and how competent they are using them. Many students have a profitable experience using technology, seeing their computer not as an awkward, complicated tool but as a tool of the trade, much like a musical instrument for a musician. Most placements take place on-site and close to where the student is based, but new types of placements such as virtual placements are gaining currency. In virtual placements, companies send translation assignments to students via the Internet, and the students work in much the same way as freelance translators. Local, national and international companies can benefit from these virtual placements. Students must deal with their translation problems on their own and may use a wide range of technology tools such as videoconferencing (with the client), advanced search tools, information- and knowledge-retrieval tools, etc.

During their placements, students use technology to improve their translations rather than merely as part of a compulsory classroom exercise. They also need to learn new tools. Tutors may ask students to use specific tools, or students may realise they need to use new resources to deal with translation problems. For instance, students may encounter new text formats or new software for subtitling videos.

Students can observe whether they use only tools they know or also new tools, whether they use only tools proposed by their tutor or also tools proposed by themselves, whether technology is a help or a hindrance, whether they enjoy learning to use new resources or not, and whether they have more or less technology skills than their colleagues in the placement, etc.

When students lack the ability to use a certain technology they cannot turn to their teachers for solutions. The company's tutor may help the student, but not all companies have invested enough time, effort and money in technological innovation, and often the students themselves must test new tools during their placement. In some work placements students focus mainly on technological tasks, such as maintaining and updating translation memories, creating databases, aligning translations, etc. Students do not enjoy these kinds of placements, because if they are not actually translating they feel like they are not doing real translation work. But this is not necessarily true, as these kinds of tasks are part of the translation service as well.

There has also been a recent surge in on-site placements abroad (often with funding from the Erasmus programme) such us those offered by the European Graduate Placement Scheme (http://www.e-gps.org/) for postgraduate students. Technological competences are highly valued, as companies use technology to be more innovative and competitive. Companies value not only students' current knowledge of tools and resources, but also their capacity to learn and to integrate technology into the translation process. If they want a candidate who will be able to do distance work for them then technological competences will be critical in the selection process. If universities want their students to pass the selection process for international placements, they must first provide them with good technology training in class, local placement opportunities and support instruments to help them make the most of their experience.

\section{The student placement "food for thought" checklist}

This article is not a research work but an invitation to think about the technologies that can be used in work placements. A long descriptive list adapted from translation-technology courses could have been used, but each placement is different, so it is impossible to create a single list that would be applicable to all courses. I therefore adopted a different approach to ensure the list is useful for students, tutors and placement coordinators alike. I aimed to 
integrate technology in a list of professional competences for translators. In 2009 the European Master's in Translation expert group proposed a list of competences applicable to language professions or to translation, defining a "competence" as "the combination of aptitudes, knowledge, behaviour and know-how necessary to carry out a given task under given conditions" (EMT expert group, 2009).[1] This list of professional competences is suitable for placements because the focus is on achieving a good translation service, rather than on learning how to translate. Moreover, the competences are related not only to the interlinguistic and intercultural translation process, but to all factors involved in the translation service.

How can we invite students to think about the professional competences they acquire? I believe the best way to achieve this is to present a clear, direct text written in the first person so that students understand that competences are applicable to them. This proposal aims to make technology visible and to show that technological competences are inseparable from the other professional competences.

Let us take the example of placements requiring literary translation. Although, a priori, this genre requires little use of technology, students can use many technological resources to solve their translation problems, including advanced searches to find intertextual quotations, literary quotations, and context about the author and his or her work. Students could also produce various commented versions of their translations. For contemporary literature, students might also contact the author or translators working into other languages via videoconference. Students could also keep a journal of their experience and share it on a blog.

The article is designed to be practical, providing a checklist so that students, tutors and coordinators can reflect on the technologies used during work placements. Each type of competence is accompanied by the corresponding definition from the EMT expert group's proposal in small print. Then there is a table, and the left column invites students to consider what professional competences they used during their placement and the right column what technology they used. This article does not provide a full explanation of each item on the list as they are self-explanatory.

\subsection{Provision of translation services, interpersonal aspects}

- Being aware of the social role of the translator

- Knowing how to follow market requirements and job profiles (knowing how to remain aware of developments in demand)

- Knowing how to organise approaches to clients/ potential clients (marketing)

- Knowing how to negotiate with the client (to define deadlines, tariffs/invoicing, working conditions, access to information, contract, rights, responsibilities, translation specifications, tender specifications, etc.)

- Knowing how to clarify the requirements, objectives and purposes of the client, recipients of the translation and other stakeholders

- Knowing how to plan and manage one's time, stress, work, budget and ongoing training (upgrading various competences)

- Knowing how to specify and calculate the services offered and their added value

- Knowing how to comply with instructions, deadlines, commitments, interpersonal competences, team organisation

- Knowing the standards applicable to the provision of a translation service

- Knowing how to comply with professional ethics 
- Knowing how to work under pressure and with other experts, with a project head (capabilities for making contacts, for cooperation and collaboration), including in a multilingual situation

- Knowing how to work in a team, including a virtual team

- Knowing how to self-evaluate (questioning one's habits; being open to innovations; being concerned with quality; being ready to adapt to new situations/conditions) and take responsibility

[EMT expert group, 2009]

\begin{tabular}{|c|c|}
\hline Student Placement Checklist & Technologies Used \\
\hline $\begin{array}{l}\text { I have understood my role in the company, } \\
\text { in the departments and between the } \\
\text { customers and the company. }\end{array}$ & $\begin{array}{l}\square \text { I have drawn a complete organizational } \\
\text { chart of the company using a flow-chart tool, } \\
\text { identifying in particular the key players } \\
\text { involved in the translation projects. } \\
\square \text { I have drawn a complete process chart of } \\
\text { my work in the company using a flow-chart } \\
\text { tool. }\end{array}$ \\
\hline $\begin{array}{l}\text { I I have identified the company's translation } \\
\text { needs. }\end{array}$ & $\begin{array}{l}\square \text { I have listed the company's translation } \\
\text { needs in my placement portfolio, taking into } \\
\text { account genres, languages, subjects, } \\
\text { technology, etc. }\end{array}$ \\
\hline $\begin{array}{l}\text { D I have contacted clients and potential } \\
\text { clients and worked with the company's } \\
\text { marketing/sales department. }\end{array}$ & $\begin{array}{l}\square \text { I have introduced data into the database of } \\
\text { prospects and clients. } \\
\square \text { I have searched for potential clients using } \\
\text { advanced search techniques. }\end{array}$ \\
\hline $\begin{array}{l}\square \text { I have helped project managers to } \\
\text { negotiate with clients. } \\
\square \text { I have negotiated with clients. }\end{array}$ & $\begin{array}{l}\square \text { I have worked with translation project- } \\
\text { management software, introducing deadlines, } \\
\text { rates and terms and conditions; issuing } \\
\text { invoices; setting permissions; and dealing } \\
\text { with contracts, rights, responsibilities, } \\
\text { translation specifications, tender } \\
\text { specifications, etc. }\end{array}$ \\
\hline $\begin{array}{l}\text { I I have understood the requirements, } \\
\text { objectives and purposes of the translations. }\end{array}$ & $\begin{array}{l}\square \text { In my placement portfolio I have noted the } \\
\text { requirements, objectives and purposes of } \\
\text { each task. }\end{array}$ \\
\hline $\begin{array}{l}\text { I I have used time and workload } \\
\text { management strategies. }\end{array}$ & $\begin{array}{l}\square \text { I have used a time-management tool to fill } \\
\text { out timesheets for different tasks. } \\
\square \text { In my private online journal I have written } \\
\text { about the workload and time constraints. } \\
\square \text { I have identified further training I could to } \\
\text { improve my translation service and noted it in } \\
\text { my placement portfolio. }\end{array}$ \\
\hline $\begin{array}{l}\square \text { I have prepared estimates for translation } \\
\text { tasks. } \\
\square \text { I have identified how to add value to my } \\
\text { translations. }\end{array}$ & $\begin{array}{l}\square \text { I have used a budgeting tool. } \\
\square \text { I have used a professional tool to create a } \\
\text { professional-looking estimate. }\end{array}$ \\
\hline $\begin{array}{l}\text { I have complied with instructions and } \\
\text { deadlines. }\end{array}$ & $\begin{array}{l}\square \text { I have written down my thoughts on } \\
\text { instructions and deadlines in my private } \\
\text { online reflective journal. }\end{array}$ \\
\hline
\end{tabular}




\begin{tabular}{|l|l|}
\hline $\begin{array}{l}\square \text { I have complied with the company's quality } \\
\text { standards. }\end{array}$ & $\begin{array}{l}\square \text { I have applied the company's quality } \\
\text { templates and checklists in my work. } \\
\square \text { I have created my personal quality-control } \\
\text { templates and checklists. }\end{array}$ \\
\hline $\begin{array}{l}\square \text { During the placement, I have followed a } \\
\text { strictly ethical conduct }\end{array}$ & $\begin{array}{l}\square \text { In my private online reflective journal I } \\
\text { have written entries on ethical issues I have } \\
\text { encountered. }\end{array}$ \\
\hline $\begin{array}{l}\square \text { I have successfully worked under } \\
\text { pressure. } \\
\square \text { I have successfully worked in a team } \\
\square \text { I have successfully worked in a } \\
\text { multilingual situation. }\end{array}$ & $\begin{array}{l}\square \text { In my private online reflective journal I } \\
\text { have written about my work relations with } \\
\text { other employees and my experience with } \\
\text { time and workload management. }\end{array}$ \\
\hline $\begin{array}{l}\square \text { I have successfully worked in a team } \\
\text { (including a virtual team). }\end{array}$ & $\begin{array}{l}\square \text { I have used project-management software } \\
\text { to share documents and information among } \\
\text { team members. } \\
\square \text { (For virtual teams) We have held team } \\
\text { meetings via videoconference. } \\
\square \text { (For virtual placements) I have had regular } \\
\text { videoconference meetings with my company } \\
\text { tutor. }\end{array}$ \\
\hline $\begin{array}{l}\square \text { I have kept a private journal about my work } \\
\text { habits and about being open to innovation, } \\
\text { concerned with quality, and ready to adapt to } \\
\text { nork placem howt. } \\
\text { responsibilities in the company. }\end{array}$ \\
\hline
\end{tabular}

\subsection{Provision of translation services, production aspects}

- Knowing how to create and offer a translation appropriate to the client's request, i.e. to the aim/skopos and to the translation situation

- Knowing how to define stages and strategies for the translation of a document

- Knowing how to define and evaluate translation problems and find appropriate solutions

- Knowing how to justify one's translation choices and decisions

- Mastering the appropriate metalanguage (to talk about one's work, strategies and decisions)

- Knowing how to proofread and revise a translation (mastering techniques and strategies for proofreading and revision)

- Knowing how to establish and monitor quality standards

[EMT expert group, 2009]

\begin{tabular}{|l|l|}
\hline Student Placement Checklist & Technologies Used \\
\hline $\begin{array}{l}\square \text { My translation services were appropriate } \\
\text { to the client's request, i.e. to the aim/skopos } \\
\text { and the translation situation. }\end{array}$ & $\begin{array}{l}\square \text { I have created translation assignment } \\
\text { templates to include all client requests and I } \\
\text { have added them to my placement portfolio. }\end{array}$ \\
\hline $\begin{array}{l}\square \text { For the translation of documents, I have } \\
\text { followed the stages and strategies } \\
\text { established by my tutor. }\end{array}$ & $\begin{array}{l}\square \text { I have created a guide for establishing } \\
\text { stages and strategies for translations and } \\
\text { included it in my placement portfolio. }\end{array}$ \\
$\begin{array}{l}\square \text { I have defined the stages and strategies } \\
\text { for the translation of documents. }\end{array}$ & \\
\hline
\end{tabular}




\begin{tabular}{|l|l|}
\hline$\square$ I have defined and evaluated translation & I have found solutions using: \\
problems and found appropriate solutions. & $\square$ Glossaries, dictionaries, grammar \\
& manuals, encyclopaedias, etc. \\
& $\square$ Corpora: parallel corpora, ad-hoc corpora, \\
& reference corpora, historical corpora, \\
& multilingual corpora, etc. \\
& $\square$ Corpus software \\
& $\square$ Translation memories \\
& $\square$ Machine translation \\
& $\square$ Terminology databases \\
& $\square$ Search engines: direct searches, \\
& advanced searches, advanced information- \\
& mining techniques, etc. \\
& $\square$ Document databases, etc. \\
& $\square$ Style guides \\
$\square$ I have properly justified my translation & $\square$ Social media: translators' forums, mailing \\
choices and decisions using the appropriate & lists, social networks, etc. \\
metalanguage. & $\square$ I have added appropriate professional \\
\hline I have revised and proofread translations. & comments to my translations to justify my \\
$\square$ I know how to establish and monitor & $\square$ I have used quality-assessment software \\
quality standards. & when revising translations. \\
& $\square$ I have used spelling and grammar \\
& checkers. \\
& $\square$ I have used quality-assessment templates \\
& when revising translations. \\
\hline
\end{tabular}

\subsection{Language competence}

- Knowing how to understand grammatical, lexical and idiomatic structures as well as the graphic and typographic conventions of language $A$ and one's other working languages

- Knowing how to use these same structures and conventions in $A$ and $B$

- Developing sensitivity to changes in language and developments in languages (useful for exercising creativity)

[EMT expert group, 2009]

\begin{tabular}{|l|l|}
\hline Student Placement Checklist & Technologies Used \\
\hline$\square$ I have understood grammatical, lexical & I have used: \\
and idiomatic structures as well as the & $\square$ Glossaries, dictionaries, grammar manuals, \\
graphic and typographic conventions of & encyclopaedias, etc. \\
language A and my source languages (B, & $\square$ Corpora: parallel corpora, ad-hoc corpora, \\
C). & reference corpora, historical corpora, multilingual \\
$\square$ I have used appropriate structures and & corpora, etc. \\
conventions in languages A and B. & $\square$ Corpus software \\
$\square$ I have developed an awareness of & $\square$ Translation memories \\
changes in developments in languages & $\square$ Machine translation \\
(useful for exercising creativity). & $\square$ Terminology databases \\
& $\square$ Search engines: direct searches, advanced \\
& searches, advanced information-mining \\
& techniques, etc. \\
& $\square$ Document databases, etc. \\
& $\square$ Style guides \\
& $\square$ Social media: translators' forums, mailing lists, \\
& social networks, etc. \\
\hline
\end{tabular}




\subsection{Intercultural competence, sociolinguistic dimension}

- Knowing how to recognise function and meaning in language variations (social, geographical, historical, stylistic)

- Knowing how to identify the rules for interaction relating to a specific community, including non-verbal elements (useful knowledge for negotiation)

- Knowing how to produce a register appropriate to a given situation, for a particular document (written) or speech (oral)

[EMT expert group, 2009]

\begin{tabular}{|l|l|}
\hline Student Placement Checklist & Technologies Used \\
\hline$\square$ I am able to recognise functions and \\
$\begin{array}{l}\text { meanings in language variations (social, } \\
\text { geographical, historical, stylistic). }\end{array}$ & $\square$ I have used the Internet to solve language- \\
& $\begin{array}{l}\text { variation problems in my translations. } \\
\square \text { In my placement portfolio I have saved } \\
\text { useful resources on language variation in my } \\
\text { translations. }\end{array}$ \\
\hline$\square$ I am able to identify the rules for & $\square$ In my portfolio I have written the rules for \\
interaction related to my translation or & interaction in my work-placement \\
interpreting assignments. & assignments (translation or interpreting). \\
\hline$\square$ I am able to produce the appropriate & I have used: \\
register for a given situation, document & $\square$ Parallel genres (written or oral) \\
(written) or speech (oral). & $\square$ Ad-hoc corpus building (written or oral) \\
& $\square$ Internet videos \\
& $\square$ Advanced searches \\
& $\square$ Data storage methods to re-use the \\
& information in future assignments. \\
\hline
\end{tabular}

\subsection{Intercultural competence, textual dimension}

- Knowing how to understand and analyse the macrostructure of a document and its overall coherence (including where it consists of visual and sound elements)

- Knowing how to grasp the presuppositions, the implicit, allusions, stereotypes and intertextual nature of a document

- Knowing how to describe and evaluate one's problems with comprehension and define strategies for resolving those problems

- Knowing how to extract and summarise the essential information in a document (ability to summarise)

- Knowing how to recognise and identify elements, values and references proper to the cultures represented

- Knowing how to bring together and compare cultural elements and methods of composition.

- Knowing how to compose a document in accordance with the conventions of the genre and rhetorical standards

- Knowing how to draft, rephrase, restructure, condense, and post-edit rapidly and well (in languages $\mathrm{A}$ and $\mathrm{B}$ ) 


\begin{tabular}{|l|l|}
\hline Student Placement Checklist & Technologies Used \\
\hline$\square$ I have understood and analysed the & $\square$ I have identified and saved \\
macrostructure and overall coherence of & macrostructures in my portfolio. \\
documents I have translated during the & $\square$ I have kept a copy of my translations in the \\
placement (including audio and video & portfolio with comments regarding implicit \\
documents). & presuppositions, allusions, stereotypes and \\
$\square$ I have dealt with implicit presuppositions, & intertextual features in documents I \\
allusions, stereotypes and intertextual & translated during the placement. \\
features in documents I have translated & $\square$ I have created a query report to discuss \\
during the placement. & unsolved comprehension problems with the \\
$\square$ I have used suitable strategies to solve & tutor. \\
comprehension problems. & $\square$ I have written summaries of the texts to be \\
$\square$ Before translating I have summarised the & translated in my portfolio. \\
text to extract the essential information. & $\square$ I have searched for information on all the \\
$\square$ I have recognised and identified elements, & cultural elements in source texts. \\
values and references that are specific to the & $\square$ I have saved useful resources for dealing \\
cultures represented. & with cultural elements. \\
$\square$ I have compared cultural elements and & $\square$ I have searched for parallel texts. \\
writing norms. & $\square$ I have searched for genre conventions. \\
$\square$ I have checked the conventions and & $\square$ I have searched for rhetorical norms. \\
rhetorical norms of a genre when translating & $\square$ I have searched for style manuals and \\
a text. & standards. \\
$\square$ I have drafted, rephrased, restructured, & $\square$ I have used CAT tools. \\
condensed and post-edited texts. & $\square$ I have used post editing tools. \\
& $\square$ I have used spelling and grammar \\
& checkers. \\
\hline
\end{tabular}

\subsection{Information mining competence}

- Knowing how to identify one's information and documentation requirements

- Developing strategies for documentary and terminological research (including approaching experts)

Student:

- Knowing how to extract and process relevant information for a given task (documentary, terminological, phraseological information)

- Developing criteria for evaluation vis-à-vis documents accessible on the internet or any other medium, i.e.

- Knowing how to evaluate the reliability of documentary sources (critical mind)

- Knowing how to use tools and search engines effectively (e.g. terminology software, electronic corpora, electronic dictionaries)

- Mastering the archiving of one's own documents 


\begin{tabular}{|l|l|}
\hline Student Placement Checklist & Technologies Used \\
\hline$\square$ I have identified the information and & I have used: \\
documentation required for texts. & $\square$ Dictionaries, glossaries, encyclopaedias \\
$\square$ I have developed strategies for & $\square$ Random contextual searches \\
documentation and terminological research. & $\square$ Advanced contextual searches \\
$\square$ I have extracted and processed relevant & $\square$ Specialised dictionaries and glossaries \\
information for tasks. & compiled by reliable authors \\
$\square$ I have developed criteria for evaluating the & $\square$ Terminology software \\
reliability of online and other documents & $\square$ Highly specialised conceptual websites \\
(using a critical mind). & $\square$ Existing electronic corpora \\
$\square$ I have used tools and search engines & $\square$ Self-built ad-hoc corpora \\
effectively. & $\square$ Corpus-building software \\
$\square$ I have saved my own placement & $\square$ Concordancing software \\
documents. & $\square$ Terminology extractors. \\
& $\square$ I have made backup copies of all my work \\
& and useful resources. \\
& $\square$ My work was stored in the company's \\
& backup system. \\
& $\square$ I have saved reliable documentary \\
& resources for further reference. \\
\hline
\end{tabular}

\subsection{Thematic competence}

- Knowing how to search for appropriate information to gain a better grasp of the thematic aspects of a document (cf. Information mining competence)

- Learning to develop one's knowledge in specialist fields and applications (mastering systems of concepts, methods of reasoning, presentation, controlled language, terminology, etc.) (learning to learn)

- Developing a spirit of curiosity, analysis and summary

[EMT expert group, 2009]

\begin{tabular}{|l|l|}
\hline Student Placement Checklist & Technologies Used \\
\hline$\square$ I have searched for appropriate & $\square$ I have used the Wikipedia. \\
information to better understand the content & $\square$ I have used Google Books and Google \\
of a document (cf. information-mining & Scholar. \\
competence) & $\square$ I have read specialised websites and \\
$\square$ I have learned to develop my knowledge in & journals. \\
specialist fields and applications (conceptual & $\square$ I have used specialised databases (legal, \\
systems, presentation methods, controlled & medical, etc.). \\
language, terminology, etc.) (learning to & $\square$ I have prepared a list of useful and reliable \\
learn). & links related to the topic of the translation. \\
$\square$ I have developed an inquisitive mindset & $\square$ I have used conceptual-diagram tools. \\
and learnt to analyse and summarise. & $\square$ I have prepared a thematic dossier and \\
& included it in my portfolio. \\
& $\square$ I have written to specialists through social \\
& networks and mailing lists. \\
& $\square$ I have shared my list of useful and reliable \\
& thematic resources with other translators. \\
\hline
\end{tabular}




\subsection{Technological competence}

- Knowing how to use effectively and rapidly and to integrate a range of software to assist in correction, translation, terminology, layout, documentary research (for example text processing, spell and grammar check, the internet, translation memory, terminology database, voice recognition software)

- Knowing how to create and manage a database and files

- Knowing how to adapt to and familiarise oneself with new tools, particularly for the translation of multimedia and audiovisual material

- Knowing how to prepare and produce a translation in different formats and for different technical media

- Knowing the possibilities and limits of MT

[EMT expert group, 2009]

\begin{tabular}{|l|l|}
\hline Student Placement Checklist & Technologies Used \\
\hline$\square$ I can quickly and effectively use a range & During the placement, I have used the \\
of software to help me translate, revise, find & following software tools: \\
terminology, arrange page layouts, and & $\square$ Word processors: \\
research information. & $\square$ Spelling and grammar checkers: \\
& $\square$ CAT tools: \\
& $\square$ Localization tools: \\
& $\square$ Terminology databases: \\
& $\square$ Desktop publishing \\
& software: \\
& $\square$ Voice-recognition software: \\
& $\square$ Text-alignment software: \\
& $\square$ Others: \\
\hline$\square$ I am able to create and manage a & $\square$ I have created or managed databases and \\
database and manage files. & managed files using these tools and file \\
& formats: \\
\hline$\square$ I am able to learn and adapt to new tools, & $\square$ Tools proposed by the tutor that I have \\
particularly those used for translating & used for the first time during my placement: \\
multimedia content. & $\square$ Tools I discovered myself and used for the \\
& first time during my placement: \\
& $\square$ Software I have used for localising \\
& multimedia content: \\
& $\square$ Software I have used for translating \\
& audiovisual content: \\
\hline$\square$ I am able to prepare and produce & I have translated documents in the following \\
translations in different formats and for & formats: \\
different technical media. & $\square$ (.fm) Adobe FrameMaker \\
& $\square$ (.inx) Adobe InDesign \\
& $\square$ (.txt, csv) text files \\
& $\square$ (.csv) character-delimited files \\
& $\square$ (.htm, .html, .xml) HTML and XML \\
& $\square$ (.properties) Java \\
& $\square$ (.xls, .xlsx) MS Excel \\
& $\square$ (.ppt, .pptx, .pps) MS PowerPoint \\
& $\square$ (.doc, .docx, .dot) MS Word \\
& $\square$ (.otd) OpenOffice \\
\hline
\end{tabular}




\begin{tabular}{|l|l|}
\hline & $\square$ (.pdf) portable document format \\
& $\square$ (.rff) rich text format \\
& $\square$ (.dll, .exe, .rc) software formats \\
& $\square$ Others: \\
& $\square$ I have translated these types of \\
& documents: \\
& $\square$ Printed material \\
& $\square$ Digital material \\
& $\square$ Web content \\
& $\square$ E-books \\
& $\square$ Mobile devices \\
& $\square$ Videogames \\
& $\square$ Audiovisual formats \\
& $\square$ Others: \\
\hline$\square$ I understand the possibilities and limits of & $\square$ I have used MT software. \\
machine translation & $\square$ I have used post-editing software. \\
\hline
\end{tabular}

\section{Conclusion}

Despite the fact that the inclusion of some items in the table might seem slightly forced, this exercise does not pretend to build a solid reflective model but to make visible the technologies used during work placements, and relate them to professional competences. In fact, many graduates are aware of the technological skills they still lack when they graduate. When they begin to search for a job, they often realise that technology is more important than they imagined. If they have the chance to be aware of this during their work placements, they might look for a way to solve their technological shortcomings.

\section{References}

EMT expert group. (2009). Competences for professional translators, experts in multilingual and multimedia communication <http://ec.europa.eu/dgs/translation/programmes/emt/index_en.htm> Last update: January 2009. Consultation date: August 2013.

[1] Available for download at <http://ec.europa.eu/dgs/translation/programmes/emt/index_en.htm>. 